\title{
(6) OPEN ACCESS \\ Education and training to enhance end-of-life care for nursing home staff: a systematic literature review
}

\author{
Sally Anstey, ${ }^{1}$ Tom Powell, ${ }^{1}$ Bernadette Coles, $^{2}$ Rachel Hale, ${ }^{1}$ \\ Dinah Gould ${ }^{1}$
}

- Additional material is published online only. To view please visit the journal online (http://dx.doi.org/10.1136/ bmjspcare-2015-000956)

${ }^{1}$ School of Healthcare Sciences, Cardiff University, Cardiff, UK

${ }^{2}$ Cancer Research Wales (CRW) Library, Velindre National Health Trust, Cardiff, UK

\section{Correspondence to} Rachel Hale, School of Healthcare Sciences, Cardiff University, Eastgate House, Newport Road, Cardiff CF24 OAB, UK; haler1@cardiff.ac.uk

Received 18 June 2015 Revised 9 February 2016 Accepted 5 May 2016 Published Online First 21 June 2016

\section{(1) crossark}

To cite: Anstey $S$, Powell T, Coles $\mathrm{B}$, et al. BMJ Supportive \& Palliative Care 2016:6:353361.

\section{ABSTRACT}

Background The delivery of end-of-life care in nursing homes is challenging. This situation is of concern as $20 \%$ of the population die in this setting. Commonly reported reasons include limited access to medical care, inadequate clinical leadership and poor communication between nursing home and medical staff. Education for nursing home staff is suggested as the most important way of overcoming these obstacles.

Objectives To identify educational interventions to enhance end-of-life care for nursing home staff and to identify types of study designs and outcomes to indicate success and benchmark interventions against recent international guidelines for education for palliative and end-of-life care.

Design Thirteen databases and reference lists of key journals were searched from the inception of each up to September 2014. Included studies were appraised for quality and data were synthesised thematically.

Results Twenty-one studies were reviewed. Methodological quality was poor. Education was not of a standard that could be expected to alter clinical behaviour and was evaluated mainly from the perspectives of staff: selfreported increase in knowledge, skills and confidence delivering care rather than direct evidence of impact on clinical practice and patient outcomes. Follow-up was often short term, and despite sound economic arguments for delivering effective end-of-life care to reduce burden on the health service, no economic analyses were reported.

Conclusions There is a clear and urgent need to design educational interventions that have the potential to improve end-of-life care in nursing homes. Robust evaluation of these interventions should include impact on residents, families and staff and include economic analysis.

\section{BACKGROUND}

End-of-life is defined as life in the year immediately before the death of an individual with advanced illness, regardless of whether they receive palliative care. ${ }^{1}$ Effective care during life-limiting illness is important for the individual and their families for compassionate reasons. If effective, end-of-life care enables people with the advanced, progressive, incurable disease during the last year of life to remain comfortable. Distressing symptoms (eg, breathlessness, pain, fatigue and anxiety) will be controlled and individuals will be able to die with dignity, with their wishes respected, and families are also more likely to report satisfaction with care. ${ }^{2}$

Managing palliative and end-of-life care has recently been identified as a priority in nursing homes that currently provide support for large numbers of frail older people with multi-morbidities requiring complex care. ${ }^{3}$ In the UK alone, there are 12000 nursing homes offering care for half a million people. ${ }^{4}$ Numbers will increase in line with demographic and societal trends, reflecting the global situation. ${ }^{5}$ The societal and economic arguments for delivering effective end-of-life care are powerful. ${ }^{2}$ Twenty per cent of residents eventually die in nursing homes although they were not terminally ill when admitted. Moreover, unplanned hospital admissions from nursing homes are common because the end-of-life period is not well managed. ${ }^{6}$ If such admissions could be reduced through improved end-of-life care, inpatient care would be reserved for the acutely ill, reducing the burden on the health service. ${ }^{3}$

Despite the recognised need for nursing home staff to offer expertise in 
palliative and end-of-life care, numerous barriers to delivering it have been identified. One of the most common is lack of caring expertise: most direct care is delivered by unqualified support workers with a high rate of staff turnover, supervised by small numbers of qualified nurses. ${ }^{3}$ Difficulties are compounded by the multifaceted needs of the nursing home population where multi-morbidity is the norm. ${ }^{3}$ Residents are frail and dependent, and 50\% have dementia. ${ }^{5}$

At present, medical and nursing care address the needs of people with specific conditions rather than those with multi-morbidities, resulting in fragmented service provision, gaps in provision and service overlap. ${ }^{7}$ Additional reported barriers to addressing the complex needs of nursing home residents include inadequate clinical leadership, poor communication between nursing home and medical staff ${ }^{3}$ and failure of relatives and staff to either recognise or acknowledge that death is approaching in part because of the societal taboo surrounding death and discussing it. ${ }^{8}$

The single most important factor believed to confound the delivery of end-of-life care in nursing homes is the absence of appropriate education and training for staff: there are reports that they are not able to control distressing symptoms, communicate with residents, families, general practitioners and hospital staff or to co-ordinate services for people at the end of life. ${ }^{3}$

International guidelines ${ }^{9}$ for education to enable staff to deliver palliative care are designed for application in a range of settings categorised according to the needs of staff for generalist or more specialised education and training. Nursing homes are identified as generalist settings in which all staff need to know how to apply the principles of palliative and end-of-life care for residents and families but do not need specialist knowledge and skills, although they should be able to recognise when these are required and know where to seek the requisite expertise. The guidelines ${ }^{9}$ recommend that all health workers should understand the physical, psychological, social and spiritual issues that affect people with life-limiting conditions, recognise the requirements of different cultural groups and be able to adopt a palliative care approach as soon as the individual enters the end-of-life period. Drawing on the educational literature generally, androgogic principles are identified as the most appropriate and the guidelines recommend an interdisciplinary approach where possible. It is recommended that content is delivered by clinicians and academics taking cases from clinical practice to encourage discussion and reflection on the complex ethical, moral and practical challenges of delivering palliative and end-of-life care. Educational delivery should be based on different modalities including blended learning. This would enable participants to progress at their own pace without depending on classroom-based approaches: releasing staff to attend study days and providing clinical cover are recognised as specific barriers to educating health workers in nursing homes. ${ }^{10}$

The aim of this review was to systematically search and synthesise the literature to identify and critique interventions intended to improve end-of-life care in nursing homes and benchmark the most recently published interventions against international guidelines ${ }^{9}$ for education for palliative care.

\section{METHODS OF THE REVIEW}

\section{Literature review question}

Do educational interventions intended to enhance end-of-life care for nursing home staff promote better outcomes for nursing home residents?

\section{Aims}

The aims of the review were to identify:

1. Types of educational interventions used to enhance end-of-life care in nursing homes.

2. Types of study designs.

3. Outcomes taken to indicate success of educational interventions.

4. Hallmarks of effective educational provision for end-of-life care in nursing homes.

5. Benchmark educational interventions against recent international guidelines for education for palliative care. ${ }^{9}$

The review was based on the steps and processes shown in figure 1 and was informed by the PRISMA standards ${ }^{11}$ for reporting systematic reviews.

A search of 13 electronic databases was made on 12 September 2014, which included MEDLINE, MEDLINE in Process \& daily update, Embase, Cochrane Library, AMED (Allied and Complementary Medicine database), CINAHL (Cumulative Index to Nursing \& Allied Health Literature), Scopus, BNI (British Nursing Index), ERIC (Education Resources Information Centre), British Education Index, Opengrey, Joanna Briggs Institute and Pubmed. The search strategy of key terms used for Medline can be found in online supplementary appendix 1 , and this was modified so that subject headings appropriate to each database were selected together with text word terms. References from the identified studies were screened for potential works eligible to be included.

\section{Search Methodology \\ -Aims for the review are clearly identified \\ - Literature was identified according to a robust search strategy that was subject to ongoing refinement \\ - Studies were selected according to explicit inclusion/exclusion criteria by two reviewers \\ - Shortlisted Studies were summarised using an agreed format and presented to all team members for approval to produce final sample list \\ -Data extraction was undertaken by four reviewers \\ - A summary and synthesis of final sample studies was produced \\ - Thematic analysis was an ongoing and iterative process involving all team members}

Figure 1 Search methodology. 
Key journals were hand searched (Palliative Medicine, BMJ Palliative and Supportive Care, BMC Palliative Care and International Journal of Palliative Nursing).

\section{Inclusion criteria}

Full text papers reporting empirical studies evaluating educational interventions to enhance end-of-life care in nursing homes were included. There were no language restrictions. Studies that included medical staff as part of a mixed population of health workers were eligible.

\section{Exclusion criteria}

We excluded interventions where the sample consisted entirely of practitioners who would not be expected to rely on educational provision about end-of-life care delivered within the nursing home setting (eg, sample consisting only of medical staff). We excluded studies where the intervention was aimed at a single patient group (eg, cancer and dementia). We excluded studies aimed at single patient groups in nursing homes because it is the norm for residents to suffer from multiple chronic conditions rather than a single condition.

\section{Study selection}

A long list of potentially eligible studies was created by two reviewers who reported back to all team members. One study was removed from the long-list because there were no data to extract. ${ }^{12}$ Methodological quality was judged according to the CASP criteria $^{13}$ for trials. Robust methods were employed throughout the review, ${ }^{11}$ with analysis an ongoing and iterative process involving all team members. Multiple full-team consensus meetings were held to generate a final short list.

\section{Data extraction}

A standardised template developed especially for the review was used to extract the required information. Data extraction covered:

1. Design of the educational intervention: content, mode of delivery, length and number of education and training sessions.

2. Study design: aims, methodological approach, sample and results.

3. Types of outcome measures (patient/family, and/or staff-related).

4. Evaluation of the education: evaluation tools, time of the evaluation in relation to the intervention, stakeholders who contributed and impact on staff.

5. Number and timing of follow-up data collection episodes.

6. Evidence of economic analysis.

\section{RESULTS}

The searches identified 1791 papers, and of these, $19^{14-32}$ evaluated educational interventions in nursing homes (see figure 2). Two additional papers were identified through hand searching ${ }^{33}{ }^{34}$. Studies were undertaken in the UK, USA, Canada, Scandinavia and Hong Kong. The data extracted from the 21 studies are presented in table 1 .

\section{Types of interventions to enhance end-of-life care in nursing homes}

Educational approaches included didactic sessions, workshops and scenario-based learning. There were no reports of e-learning, blended learning or reflective practice. Educational content was designed to improve knowledge of end-of-life and palliative care, increase the confidence of staff caring for residents and their families and encourage more positive attitudes towards end-of-life care. The length of the educational intervention, the amount and type of material covered and the timing and frequency of follow-up were not clear. Most interventions were very brief: for example, a 1-hour lecture, ${ }^{15}{ }^{18}$ three taught sessions ${ }^{20}$ or four national workshops each attended once by participants. ${ }^{23}$ The most extensive input consisted of a study day once a month held over 6 months. ${ }^{28}$ Some authors did not provide details of the educational intervention. 222729

\section{Outcomes taken to indicate success of educational interventions}

Studies fell into two categories: those focusing entirely on outcomes relating to staff and those that included patient-related in addition to staff-related outcomes.

Interventions reporting staff-related outcomes only

Impact of the intervention was assessed mainly through staff self-reported changes in knowledge, attitudes and confidence delivering end-of-life care employing questionnaires designed especially for the study, with little or no attempt at validation. Five research teams employed validated tools. ${ }^{14} 17243233$ In one, ${ }^{17}$ an inappropriate measure (the Hospital Anxiety and Depression Scale) ${ }^{35}$ was used to assess staff anxiety and depression when caring for residents

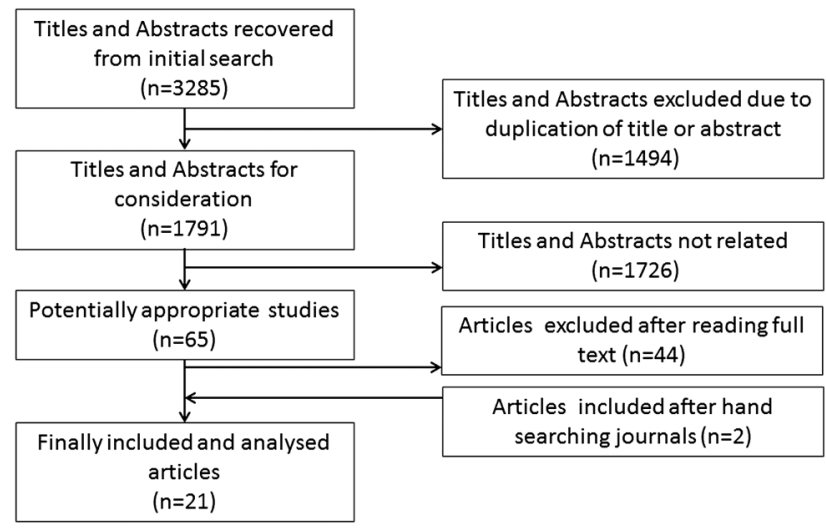

Figure 2 Search results. 


\begin{tabular}{|c|c|c|c|c|c|c|c|c|c|}
\hline \multicolumn{5}{|l|}{ Methods } & \multicolumn{5}{|l|}{ Evaluation } \\
\hline Author & Aims & Study design & Sample & Evaluation tools & Outcomes & $\begin{array}{l}\text { Evaluation } \\
\text { approach }\end{array}$ & $\begin{array}{l}\text { Number of } \\
\text { follow-ups- } \\
\text { sustainability }\end{array}$ & $\begin{array}{l}\text { Source of } \\
\text { evaluation }\end{array}$ & Results \\
\hline $\begin{array}{l}\text { Mullins and } \\
\text { Merriam }^{14}\end{array}$ & $\begin{array}{l}\text { Measure impact } \\
\text { of training } \\
\text { programme }\end{array}$ & $\begin{array}{l}\mathrm{CRCT}^{*} \text { with } \\
\text { dissimilar levels } \\
\text { of knowledge } \\
\text { between groups }\end{array}$ & $\begin{array}{l}4 \text { nursing homes; } \\
138 \text { qualified and } \\
\text { unqualified staff }\end{array}$ & $\begin{array}{l}\text { Validated } \\
\text { instrument; } \\
\text { adapted } \\
\text { non-validated } \\
\text { instrument }\end{array}$ & $\begin{array}{l}\text { Specialist } \\
\text { knowledge, } \\
\text { attitude change, } \\
\text { death anxiety }\end{array}$ & $\begin{array}{l}\text { Pre and post } \\
\text {-query } \\
\text { immediate? }\end{array}$ & None & Staff & $\begin{array}{l}\text { Test group knowledge increased, } \\
\text { attitudes were unchanged, } \\
\text { anxiety about death increased }\end{array}$ \\
\hline $\begin{array}{l}\text { Dowding and } \\
\text { Homer }{ }^{15}\end{array}$ & $\begin{array}{l}\text { Measure impact } \\
\text { of workshop }\end{array}$ & UCBAt & $\begin{array}{l}1 \text { nursing home; } 46 \\
\text { unqualified staff }\end{array}$ & $\begin{array}{l}\text { Customised } \\
\text { non-validated } \\
\text { instrument; } \\
\text { informal feedback }\end{array}$ & $\begin{array}{l}\text { Training } \\
\text { satisfaction }\end{array}$ & Unclear & None & $\begin{array}{l}\text { Educators and } \\
\text { organisation }\end{array}$ & $\begin{array}{l}\text { Workshops were positively } \\
\text { evaluated }\end{array}$ \\
\hline Froggatt $^{16}$ & $\begin{array}{l}\text { Measure impact } \\
\text { of education } \\
\text { project }\end{array}$ & $\begin{array}{l}\text { UCBA† with no } \\
\text { baseline data }\end{array}$ & $\begin{array}{l}4 \text { nursing homes; } \\
341 \text { qualified and } \\
\text { unqualified staff }\end{array}$ & $\begin{array}{l}\text { Customised } \\
\text { non-validated } \\
\text { instrument; } \\
\text { interviews and } \\
\text { observation }\end{array}$ & $\begin{array}{l}\text { Patient care, } \\
\text { training } \\
\text { satisfaction, } \\
\text { organisational } \\
\text { system }\end{array}$ & $\begin{array}{l}\text { Post (no } \\
\text { baseline data) }\end{array}$ & $\begin{array}{l}\text { Follow-up postal } \\
\text { survey after } \\
12 \text { months (end of } \\
2 \text {-year project) }\end{array}$ & $\begin{array}{l}\text { Organisation, } \\
\text { staff, patients } \\
\text { and relatives }\end{array}$ & $\begin{array}{l}\text { Organisational practice was } \\
\text { changed, but individual practice } \\
\text { was unchanged }\end{array}$ \\
\hline Thulesius et $a l^{17}$ & $\begin{array}{l}\text { Measure impact } \\
\text { of programme }\end{array}$ & CBA $\ddagger$ & $\begin{array}{l}2 \text { nursing homes: } \\
185 \text { qualified and } \\
\text { unqualified staff }\end{array}$ & $\begin{array}{l}\text { Validated } \\
\text { instrument }\end{array}$ & $\begin{array}{l}\text { Attitude change, } \\
\text { death anxiety }\end{array}$ & $\begin{array}{l}\text { Pre-test and } \\
\text { post-test } \\
1 \text { year apart }\end{array}$ & None & Staff & $\begin{array}{l}\text { Improved attitudes towards } \\
\text { end-of-life care and staff mental } \\
\text { health well-being }\end{array}$ \\
\hline Braun and $\mathrm{Zir}^{18}$ & Not stated & UCBA & $\begin{array}{l}4 \text { nursing homes; } \\
144 \text { qualified and } \\
\text { unqualified staff }\end{array}$ & $\begin{array}{l}\text { Customised } \\
\text { non-validated } \\
\text { instrument }\end{array}$ & $\begin{array}{l}\text { Specialist } \\
\text { knowledge, } \\
\text { patient care }\end{array}$ & Pre and post & None & Staff & $\begin{array}{l}\text { Self-rated knowledge increased } \\
\text { after intervention }\end{array}$ \\
\hline Parks et $a l^{19}$ & $\begin{array}{l}\text { Measure impact } \\
\text { of educational } \\
\text { programme }\end{array}$ & $\begin{array}{l}\text { UCBA with } \\
12 \text {-month } \\
\text { follow-up }\end{array}$ & $\begin{array}{l}1 \text { nursing home; } 32 \\
\text { unqualified nurses, } \\
\text { social workers and } \\
\text { support staff }\end{array}$ & $\begin{array}{l}\text { Customised } \\
\text { non-validated } \\
\text { instrument }\end{array}$ & $\begin{array}{l}\text { Specialist } \\
\text { knowledge, } \\
\text { attitude change, } \\
\text { staff confidence }\end{array}$ & $\begin{array}{l}\text { Pre course. } \\
\text { Immediate } \\
\text { post course }\end{array}$ & $\begin{array}{l}\text { 1-year follow-up with } \\
\text { same questionnaire }\end{array}$ & Staff & $\begin{array}{l}\text { Improved knowledge and } \\
\text { attitudes to end-of-life care }\end{array}$ \\
\hline Easom et a $\left.\right|^{20}$ & $\begin{array}{l}\text { Measure impact } \\
\text { of educational } \\
\text { sessions }\end{array}$ & UCBA & $\begin{array}{l}\text { Number of nursing } \\
\text { homes not } \\
\text { disclosed; } 9 \text { nursing } \\
\text { staff }\end{array}$ & $\begin{array}{l}\text { Adapted } \\
\text { non-validated } \\
\text { instrument }\end{array}$ & $\begin{array}{l}\text { Specialist } \\
\text { knowledge and } \\
\text { attitudes }\end{array}$ & $\begin{array}{l}\text { Pre course. } \\
\text { Immediate } \\
\text { post course }\end{array}$ & None & Staff & $\begin{array}{l}\text { The course was positively } \\
\text { evaluated and there was change } \\
\text { in attitude to what constitutes } \\
\text { 'good death' }\end{array}$ \\
\hline Knight et $a^{21}$ & $\begin{array}{l}\text { Assess impact of } \\
\text { integrated care } \\
\text { pathway }\end{array}$ & UCBA & $\begin{array}{l}29 \text { care homes; } 320 \\
\text { nursing staff }\end{array}$ & $\begin{array}{l}\text { Customised } \\
\text { non-validated } \\
\text { instrument; audit of } \\
\text { case notes }\end{array}$ & Patient care & Unclear & None & Staff & $\begin{array}{l}\text { Staff perceptions at care was } \\
\text { good, but this result was not } \\
\text { corroborated by case note audit }\end{array}$ \\
\hline Waldron et $a l^{22}$ & $\begin{array}{l}\text { Assess impact of } \\
\text { course }\end{array}$ & UCBA & $\begin{array}{l}\text { Number of nursing } \\
\text { homes not } \\
\text { disclosed; } 30 \\
\text { nursing staff }\end{array}$ & $\begin{array}{l}\text { Adapted } \\
\text { non-validated } \\
\text { instrument }\end{array}$ & $\begin{array}{l}\text { Training } \\
\text { satisfaction, } \\
\text { specialist } \\
\text { knowledge }\end{array}$ & Unclear & None & Staff & $\begin{array}{l}\text { The course was well evaluated, } \\
\text { but } 83 \% \text { staff had not cascaded } \\
\text { education because of time } \\
\text { pressures }\end{array}$ \\
\hline Badger et $a l^{23}$ & $\begin{array}{l}\text { Evaluation of gold } \\
\text { standards } \\
\text { framework }\end{array}$ & UCBA & $\begin{array}{l}95 \text { nursing homes; } \\
\text { number of staff } \\
\text { unclear }\end{array}$ & Audit of case notes & Patient care & Unclear & None & Unclear & Statistically significant result \\
\hline
\end{tabular}




\begin{tabular}{|c|c|c|c|c|c|c|c|c|c|}
\hline \multicolumn{5}{|l|}{ Methods } & \multicolumn{5}{|l|}{ Evaluation } \\
\hline Author & Aims & Study design & Sample & Evaluation tools & Outcomes & $\begin{array}{l}\text { Evaluation } \\
\text { approach }\end{array}$ & $\begin{array}{l}\text { Number of } \\
\text { follow-ups- } \\
\text { sustainability }\end{array}$ & $\begin{array}{l}\text { Source of } \\
\text { evaluation }\end{array}$ & Results \\
\hline Arcand et $a l^{24}$ & $\begin{array}{l}\text { Assess family } \\
\text { satisfaction }\end{array}$ & UCBA & $\begin{array}{l}1 \text { nursing home; } \\
\text { number of staff } \\
\text { unclear }\end{array}$ & $\begin{array}{l}\text { Validated } \\
\text { instruments }\end{array}$ & $\begin{array}{l}\text { Family satisfaction } \\
\text { with care }\end{array}$ & Pre-post & $\begin{array}{l}\text { Post-intervention } \\
\text { evaluation at } \\
7 \text { months }\end{array}$ & Relatives & No significant difference \\
\hline Hockley et $a^{26}$ & $\begin{array}{l}\text { Evaluate impact } \\
\text { of two end-of-life } \\
\text { packages }\end{array}$ & UCBA & $\begin{array}{l}7 \text { nursing homes; } \\
\text { staff not disclosed }\end{array}$ & $\begin{array}{l}\text { Audit of case } \\
\text { notes; interviews }\end{array}$ & Patient care & Unclear & None & Staff, relatives & $\begin{array}{l}\text { Improvement in all outcome } \\
\text { measures }\end{array}$ \\
\hline $\begin{array}{l}\text { Raunkiaen and } \\
\text { Timm }^{27}\end{array}$ & $\begin{array}{l}\text { Improving staff } \\
\text { and } \\
\text { organisational } \\
\text { competencies }\end{array}$ & Unclear & $\begin{array}{l}\text { Number of nursing } \\
\text { homes not } \\
\text { disclosed; } 22 \\
\text { nursing staff }\end{array}$ & Focus groups & $\begin{array}{l}\text { Specialist } \\
\text { knowledge }\end{array}$ & Unclear & None & $\begin{array}{l}\text { Staff and } \\
\text { educators }\end{array}$ & $\begin{array}{l}\text { Competencies in palliative care } \\
\text { were reported to have increased } \\
\text { and there was improvement in } \\
\text { organisational purpose (not } \\
\text { defined) }\end{array}$ \\
\hline Gatchell et $a^{28}$ & $\begin{array}{l}\text { Increased use of } \\
\text { care concepts }\end{array}$ & UCBA & $\begin{array}{l}5 \text { nursing homes; } \\
124 \text { qualified and } \\
\text { unqualified nursing } \\
\text { home staff }\end{array}$ & $\begin{array}{l}\text { Customised } \\
\text { non-validated } \\
\text { instrument }\end{array}$ & Patient care & $\begin{array}{l}\text { Immediate } \\
\text { post every } \\
\text { session }\end{array}$ & None & Staff & $\begin{array}{l}\text { Application of palliative care } \\
\text { concepts increased and was } \\
\text { better for staff attending three } \\
\text { or more of a total of six } \\
\text { sessions }\end{array}$ \\
\hline $\begin{array}{l}\text { Letizia and } \\
\text { Jones }^{29}\end{array}$ & $\begin{array}{l}\text { Evaluate an } \\
\text { educational } \\
\text { programme }\end{array}$ & UCBA & $\begin{array}{l}\text { Number of nursing } \\
\text { homes not } \\
\text { disclosed; } 107 \\
\text { nursing staff }\end{array}$ & $\begin{array}{l}\text { Adapted validated } \\
\text { instrument }\end{array}$ & $\begin{array}{l}\text { Knowledge, staff } \\
\text { confidence, } \\
\text { training } \\
\text { satisfaction }\end{array}$ & Pre and post & None & Staff & $\begin{array}{l}\text { Knowledge and confidence } \\
\text { increased, self-reported changes } \\
\text { in practice were documented, } \\
\text { the programme was well } \\
\text { evaluated }\end{array}$ \\
\hline Finucane et $a^{30}$ & $\begin{array}{l}\text { Follow-up of } \\
\text { Hockley et } a^{26}\end{array}$ & $\begin{array}{l}\text { Follow-up of } \\
\text { Hockley et } a^{26}\end{array}$ & $\begin{array}{l}7 \text { nursing homes; } \\
20 \text { qualified and } \\
\text { unqualified staff } \\
\text { including managers, } \\
\text { GPs and support } \\
\text { staff }\end{array}$ & Audit of case notes & Patient care & $\begin{array}{l}\text { Throughout } \\
\text { intervention }\end{array}$ & None & Unclear & $\begin{array}{l}\text { Quality of care on all outcome } \\
\text { measures declined }\end{array}$ \\
\hline Lee et $a l^{\beta 1}$ & $\begin{array}{l}\text { Impact of } \\
\text { educational } \\
\text { programme }\end{array}$ & UCBA & $\begin{array}{l}\text { Number of nursing } \\
\text { homes not } \\
\text { disclosed; } 660 \\
\text { nursing staff }\end{array}$ & $\begin{array}{l}\text { Customised } \\
\text { non-validated } \\
\text { instrument }\end{array}$ & $\begin{array}{l}\text { Specialist } \\
\text { knowledge, } \\
\text { attitude change }\end{array}$ & Pre and post & None & Staff & Knowledge improved \\
\hline Pitman $^{32}$ & $\begin{array}{l}\text { Measure impact } \\
\text { of self-learning } \\
\text { package }\end{array}$ & UCBA & $\begin{array}{l}3 \text { nursing homes; } \\
33 \text { nursing staff }\end{array}$ & $\begin{array}{l}\text { Validated } \\
\text { instrument }\end{array}$ & $\begin{array}{l}\text { Knowledge } \\
\text { confidence }\end{array}$ & Pre and post & $\begin{array}{l}\text { 6-Month postal } \\
\text { follow-up }\end{array}$ & Staff & $\begin{array}{l}\text { Knowledge and confidence } \\
\text { increased }\end{array}$ \\
\hline
\end{tabular}


at the end of life. One of the interventions in this category employed a solely qualitative approach. ${ }^{27}$

Interventions reporting staff-related and patient-related outcomes

Two research teams took a mixed methods approach to data collection ${ }^{26}{ }^{34}$ in which objective patient/ family derived data were triangulated with data from staff. Two studies ${ }^{23} 30$ obtained patient-related data through case note audit that included: evidence of advanced care plans, ${ }^{23}{ }^{26}$ number of unplanned hospital admissions, ${ }^{23}{ }^{30}$ do not resuscitate requests, ${ }^{26} 30$ anticipatory care plans, ${ }^{30}$ Liverpool Care Pathway, ${ }^{26} 3034$ preferred place of death ${ }^{25}$ and evidence of support for bereaved families. ${ }^{30}$ Five authors $^{15} \quad 16 \quad 18 \quad 28 \quad 31$ did not explain how data had been collected. One study obtained data by interviewing bereaved families. ${ }^{24}$ Data were never obtained from nursing home residents and there were no reports of economic evaluation.

\section{Robustness of the evidence}

Most interventions employed an uncontrolled before and after (pre-post test) study design. There was one cluster randomised controlled trial ${ }^{14}$ in which measures of knowledge and attitudes about end-of-life care and anxiety about death in the control and test groups were significantly different at the preintervention stage. As a result, the impact of the intervention on these outcome measures is difficult to assess. In one controlled before and after study, ${ }^{16}$ reporting of baseline data was unclear, and in one initiative, the study design was unclear. ${ }^{27}$ Four studies were undertaken in a single nursing home. ${ }^{15} 192434$ Eight studies ${ }^{14}$ 16-18 26283032 were undertaken with larger samples (2-10 nursing homes). Three studies $^{21} 2333$ took place in 20 homes or more. The number of staff taking part varied between 7 and over 600 , but the norm was for small sample sizes (see table 1). Participants were usually nurses and support workers although occasionally managers were included. There was no evidence that power calculations or any other rationale had been used to determine sample size.

\section{DISCUSSION}

The review corroborates the widely held belief and recent evidence ${ }^{3}$ that educational provision for nursing home staff is poor. However, there is insufficient evidence to determine whether educational interventions intended to enhance end-of-life care for nursing home staff can promote better outcomes for nursing home residents or the health service. The studies reviewed suffer from limitations in terms of methodological quality, the interventions were not credible as a means of improving end-of-life care, outcome measures were poorly chosen and the studies contained biases likely to influence the conclusions that can be drawn from their findings. The CASP 
criteria ask whether the results of trials are valid and if they could help improve care locally. Applying CASP, none of the studies generated valid findings and they are too poorly described for the findings to be helpful in other settings.

\section{Methodological quality}

Overall methodological quality was poor. Reporting in at least half the studies was incomplete: the type of data collected and method of data collection were frequently unclear or poorly described. No rationale was given for the number of nursing homes or staff included or how they were selected. It is possible that research teams approached nursing homes or staff where it was anticipated that interest would be shown in education and/or end-of-life care and the findings cannot be extended to nursing home staff in general. Most authors reported uncontrolled before and after studies where performance was assessed before and after the intervention had been applied. Change was inevitably attributed to the intervention. This type of study design does not provide robust evidence because it does not consider the possible impact of other changes or special circumstances that could have influenced findings. ${ }^{36}$ For example, it is very likely that educational interventions were conducted in nursing homes with particularly effective managers or those with especially good links to academic providers and are thus atypical of nursing homes in general.

The validity of the two publications ${ }^{14}{ }^{17}$ employing controlled study designs was compromised through poor sampling and unequal levels of knowledge between control and intervention groups. External validity was also compromised: only one study was underpinned by theory. ${ }^{27}$ Three studies 232630 were based on the Gold Standards Framework for End of Life Care. ${ }^{1}$

\section{Credibility of the educational interventions}

The credibility of the education was questionable. Many interventions appeared to have been 'one off' events not forming part of an ongoing culture of continuing professional development. In most cases, the brevity of the educational intervention meant that many of the complex issues surrounding end-of-life care could only have been dealt with at a superficial level or not addressed at all and would thus be unlikely to change staff behaviour or attitudes, although they might raise awareness of the need for end-of-life care. Most interventions relied on single or a small number of teaching sessions. The international guidelines ${ }^{9}$ identified potential educational content and delivery, but only three studies addressed this issue. There were three exceptions. One study ${ }^{27}$ linked competencies in palliative care to education and the delivery of organisational goals. These goals were not described. One study reported increased confidence among staff and improved delivery of end-of-life care, ${ }^{34}$ and another study ${ }^{16}$ suggested that organisational practice was changed although the individual practice of nursing home staff had not. The two studies ${ }^{30}{ }^{34}$ published since the guidelines ${ }^{9}$ appeared did not align to the guideline recommendations as they did not employ a broad range of educational modalities recommended for improving education to deliver palliative care. Moreover, the guidelines ${ }^{9}$ focus on applying palliative and end-of-life care principles developed during professional preparation, but the nursing home workforce consists mainly of support staff who have never had professional preparation.

\section{Outcome measures}

Although most authors recognised the societal costs of not providing high quality of end-of-life care, these were not reflected in the outcome measures. Economic analysis was not attempted in any study despite need to assess the impact of providing effective education for end-of-life care on cost to the health service. ${ }^{3}$ Only four studies considered objective outcomes: advanced care plans, unplanned hospital admissions, do not resuscitate requests, anticipatory care plans or use of care bundles. ${ }^{23} 263034$ In the remaining studies, outcomes were restricted to staff satisfaction with education and self-reported improvement in knowledge, ability and confidence to deliver or raise awareness of the need for end-of-life care.

Studies in the review generally employed measures that had not been validated rather than reporting any demonstrable improvement in patient care or family satisfaction with care. Obtaining data relating to patient outcomes has been identified as a challenge in studies based in nursing homes because patient records have been reported as too inadequate to provide reliable data ${ }^{37}$ perhaps explaining why this approach is seldom taken.

Data are not obtained from families, probably because this approach has traditionally been considered insensitive and objections are likely to be raised by ethics committees. ${ }^{2}$ However, where this approach has been attempted, it has been reported as acceptable and considered successful. ${ }^{2}$

\section{Sources of bias}

All the studies reported positive outcomes, suggesting publication bias (the tendency for authors, referees and journal editors to favour the publication of studies reporting positive outcomes). Delivery of the education and evaluation were usually conducted by the same team, introducing a further source of bias.

\section{Other issues}

Few studies incorporated qualitative data or attempted to incorporate data from different sources, giving an incomplete picture of the impact of the intervention. There was little effort to establish whether the reported changes achieved by the intervention were sustainable over time. 


\section{LIMITATIONS OF THE REVIEW}

Searches were conducted from the inception of the databases up to September 2014 when this review was submitted for publication. It is possible that additional relevant papers have since been published. We included nursing homes and long-term care facilities, but their patient populations and the structure and delivery of services might not be the same, limiting the conclusions that can be drawn by considering them collectively.

\section{CONCLUSIONS}

Although education is widely regarded as the single most important way of improving end-of-life care delivered by nursing home staff, existing educational interventions appear unlikely to promote better patient outcomes and evidence to demonstrate their effectiveness is not robust. There is a need to design credible educational interventions and evaluate their impact on patients, families and staff in nursing homes with economic evaluation.

Contributors DG conceived and instigated the review. SA, BC and DG wrote the protocol. BC undertook the searches. SA, $\mathrm{DG}, \mathrm{TP}$ and $\mathrm{RH}$ took part in data extraction and selection of the papers. SA, TP and DG led synthesis. DG, SA and TP drafted the manuscript and commented on the final work.

Competing interests None declared.

Provenance and peer review Not commissioned; externally peer reviewed.

Open Access This is an Open Access article distributed in accordance with the Creative Commons Attribution Non Commercial (CC BY-NC 4.0) license, which permits others to distribute, remix, adapt, build upon this work noncommercially, and license their derivative works on different terms, provided the original work is properly cited and the use is non-commercial. See: http://creativecommons.org/licenses/by$\mathrm{nc} / 4.0 /$

\section{REFERENCES}

1 Gold standards framework for end of life care. http://www. goldstandardsframework.org.uk/ (accessed 18 May 2016).

2 Teno JM, Clarridge BR, Casey V, et al. Family perspectives on end-of-life-care at the last place of care. J Am Med Assoc 2004;29:88-93.

3 Spilsbury K, Hanratty B, McCaughan D. Supporting nurses in care homes. University of York Project Report. 2015.

4 Laing and Buisson. Care of elderly people in UK Market Survey 2010/11. London: Laing and Buisson, 2011.

5 Bowman C, Whistler J, Ellerby M, et al. A national census of care home residents. Age Aging 2004;3:561-6.

6 Balance of Care Group and National Audit Office. Identifying alternatives to hospital for people at the end of life. Report findings. 2008. http://www.nao.org.uk/wp-content/uploads/ 2008/11/07081043 alternatives.pd (accessed 18 May 2016).

7 Barnett K, Mercer SW, Norbury M, et al. Epidemiology of multimorbidity and implications for health care research and medical education: a cross-sectional survey. Lancet 2012;380:37-43.

8 Mathie E, Goodman C, Crang C, et al. An uncertain future: the unchanging views of care home residents about living and dying. Palliat Med 2012;26:734-43.
9 Gamondi C, Larkin P, Payne S. Core competencies in palliative care: an EAPC White Paper on palliative care education-part 2. Eur J Palliat Care 2013;20:140-5.

10 Gould DJ, Kelly D, White I, et al. The impact of commissioning processes on the delivery of continuing professional education for cancer and palliative care. Nurse Educ Today 2004;24:443-51.

11 Preferred Reporting Items for Systematic Reviews and Meta-Analyses (PRISMA) Standards. http://prisma-statement. org (accessed 18 May 2016).

12 Landsell J, Mahoney M. Developing competencies for end-of-life care in care homes. Int J Palliat Nurs 2011;17:143-8.

13 CASP. http://media.wix.com/ugd/dded87_40b9ff0bf538404783 31915a8ed8b2fb.pdfhttp://media.wix.com/ugd/dded87 40b9ff0bf53840478331915a8ed8b2fb.pdf (accessed 20 Jan 2016).

14 Mullins L, Merriam S. The effects of a short-term death training program on nursing home nursing staff. Death Educ 1983;7:353-68.

15 Dowding C, Homer P. Teaching palliative care principles to UK nursing home care assistants. Int J Nurs Pract 2000;6:160-3.

16 Froggatt K. Evaluating a palliative care education project in nursing homes. Int J Palliat Nurs 2000;6:140-6.

17 Thulesius H, Petersson C, Petersson K, et al. Learner-centred education in end-of-life care improved well being in home care staff: a prospective controlled study. Palliat Med 2002;16:347-54.

18 Braun K, Zir A. Using an interactive approach to teach nursing home workers about end-of-life care. Assess Depress 2005; 795:280-8.

19 Parks A, Haines C, Foreman D, et al. Evaluation of an educational program for long-term care nursing assistants. J Am Med Dir Assoc 2005;6:61-5.

20 Easom L, Galatas S, Warda M. End-of-life care: an educational intervention for rural nurses in southeastern USA. Int J Pall Nurs 2006;12:526-34.

21 Knight G, Jordan C, Lewis M. Improving end-of-life care in the care home sector. Pract Dev Health Care 2008;7:189-97.

22 Waldron M, Hasson F, Kernohan W, et al. Evaluating education in palliative care with link nurses in nursing homes. Br J Nurs 2008;17:1078-83.

23 Badger F, Clifford C, Hewison A, et al. An evaluation of the implementation of a programme to improve end-of-life care in nursing homes. Palliat Med 2009;23:502-11.

24 Arcand M, Monette J, Monette M, et al. Educating nursing home staff about the progression of dementia and the comfort care option: impact on family satisfaction with end-of life care. J Am Med Dir Assoc 2009;10:50-5.

25 Dryden H, Addicott R. Evaluation of a pilot study day for healthcare assistants and social care officers. Int J Palliat Nurs 2009;1:6-11.

26 Hockley J, Watson J, Oxenham D, et al. The integrated implementation of two end-of-life care tools in nursing homes in the UK: an in-depth evaluation. Palliat Med 2010;24: 828-38.

27 Raunkiaen M, Timm H. Development of palliative care in nursing homes: evaluation of a Danish project. Int J Palliat Nurs 2010;16:613-20.

28 Gatchell G, Tim M, Tachibana Y, et al. An educational intervention for frontline nursing home staff on palliative care: the impress project [abstract B58(S83)]. Proceedings of the American Geriatrics Society 2011 Annual Meeting; 11-14 May 2011; National Harbor, MD USA. 
29 Letizia M, Jones T. An educational intervention for nurse practitioners providing palliative care in nursing homes. J Hosp Palliat Nurs 2012;14:351-7.

30 Finucane A, Stevenson B, Moyes R, et al. Improving end-of-life care in nursing homes: implementation and evaluation of an intervention to sustain quality of care. Palliat Med 2013;27:772-8.

31 Lee J, Cheng J, Au KM, et al. Improving the quality of end-of-life care in long-term care institutions. J Palliat Med 2013;16:1268-74.

32 Pitman S. Evaluating a self-directed palliative care learning package for rural aged care workers: a pilot study. Int J Palliat Nurs 2013;19:290-4.

33 Augustsson H, Törnquist A, Hasson H. Challenges in transferring individual learning to organizational learning in the residential care of older people. J Health Organ Manag 2013;27:390-408.

34 Farrington C. Blended e-learning and end of life care in nursing homes: a small-scale mixed-methods case study. BMC Palliat Care 2014;13:31.

35 Zigmond AS, Snaith RP. The Hospital Anxiety and Depression Scale. Acta Psychiatr Scand 1983;67:361-70.

36 Grimshaw J, Campbell M, Eccles M, et al. Experimental and quasi-experimental designs for evaluating guideline implementation strategies. Family Pract 2000;17:S11-18.

37 Hood K, Nuttall J, Gillespie D, et al. Probiotics for antibiotic-associated diarrhoea (PAAD): a prospective observational study of antibiotic-associated diarrhoea (including Clostridium difficile-associated diarrhoea) in nursing homes. Health Technol Assess 2014;18:1-84. 